\title{
Pengembangan Modul Berbasis POE (Predict Observe Explain) pada Materi Trigonometri
}

\section{Asyifa Rahmawati ${ }^{1}$, Dian Anggraini ${ }^{2}$, dan Rubhan Masykur ${ }^{3}$}

1,3Universitas Islam Negeri Raden Intan Lampung, Indonesia

${ }^{2}$ Institut Teknologi Sumatera, Indonesia

Corresponding Author: asyifarahmawati97@gmail.com?, dian.anggraini@at.itera.ac.id², rmasykur@yahoo.co.id ${ }^{3}$

DOI: http://dx.doi.org/10.15294/kreano.v10i2.20337

Received : August 1 2019; Accepted: December 4 2019; Published: December 42019

\begin{abstract}
Abstrak
Penelitian ini bertujuan untuk menghasilkan modul berbasis POE (Predict Observe Explain) yang layak, menarik dan efektiv pada materi trigonometri. Penelitian ini merupakan penelitian pengembangan dengan menggunakan model 4-D yang terdiri dari 4 tahap (define, design, develop, disseminate). Hasil yang diperoleh dari penelitian ini adalah produk berupa bahan ajar modul dengan model pembelajaran POE (Predict Observe Explain) dengan perolehan hasil uji kelayakan sebesar 3,4 untuk validasi ahli materi dengan kriteria "sangat layak" dan 3,1 untuk validasi ahli media dengan kriteria "layak". Hasil angket kemenarikan peserta didik diperoleh skor rata-rata sebesar 3,3 untuk kelompok kecil dengan kriteria "sangat menarik" dari 10 orang peserta didik dan 3,3 untuk uji kelompok besar dengan kriteria "sangat menarik" dari 30 orang peserta didik. Hasil uji efektivitas memperoleh skor sebesar 0,72 di SMAN 5 Bandar Lampung dan 0,70 untuk MAN 2 Bandar Lampung yang keduanya memiliki kriteria "tinggi". Berdasarkan hasil analisis data dapat disimpulkan bahwa pengembangan modul berbasis POE (Predict Observe Explain) pada materi trigonometri efektif diterapkan untuk jenjang SMA/MA.
\end{abstract}

\begin{abstract}
This research aims to produce a POE-based module (Predict Observe Explain) that is feasible, interesting and effective in trigonometric material. This research is a development research using a 4-D model consisting of 4 people (defining, designing, developing, disseminating). The results obtained from this study are products consisting of module teaching materials with the POE learning model (Predict Observe Explain) by agreeing to the feasibility test results of 3.4 for the validation of material experts with criteria "very valuable" and 3.1 for media expert validation with a "Worthy" proposal. The results of the students' attractiveness questionnaire obtained an average score of 3.3 for small groups with the criteria of "very interesting" from 10 students and 3.3 for large group trials with the criteria "very interesting" from 30 students. The test score obtained a score of 0.72 at SMAN 5 Bandar Lampung and 0.70 for MAN 2 Bandar Lampung which was equipped to have the criteria of "high". Based on the results of data analysis it can be concluded that the development of a POE-based module (Predict Observe Explain) on trigonometric materials is effectively applied to the level of SMA / MA.
\end{abstract}

Keywords: modul; predict observe explain; trigonometri 


\section{PENDAHULUAN}

Pada perkembangan teknologi zaman sekarang peran pendidikan sangatlah penting. Menurut Netriwati (2016) tanpa adanya pendidikan bagaikan seseorang yang sedang berjalan dijalanan yang gelap tanpa adanya penerangan sedikitpun, yang artinya pendidikan merupakan proses untuk mendapatkan metode tertentu sehingga memperoleh pengetahuan, pemahaman dan tingkah laku sesuai dengan kebutuhan. Dengan demikian, pendidikan menjadikan kebutuhan untuk memajukan perbedaan manusia. Pendidikan matematika merupakan salah satu aspek kehidupan yang memiliki peran penting dalam meningkatkan daya pikir manusia. Menurut Yusnita et al (2016) matematika merupakan sebuah ilmu pasti yang menjadi dasar daripada ilmu lainnya, sehingga antara matematika dengan ilmu yang lain selalu berkaitan yang matematika pun menjadi ilmu penting dalam dunia pendidikan. Adapun pembelajaran matematika akan berjalan secara efektif apabila didukung dengan media pembelajaran (Maskur et al, 2017). Media pembelajaran mempunyai fungsi yang sangat penting dalam proses belajar mengajar untuk meningkatkan mutu pendidikan. Salah satu media atau bahan ajar yang menarik untuk digunakan adalah modul (Putra dan Anggraeni, 2016).

Berdasarkan wawancara yang dilakukan dengan guru matematika kelas X SMA di kota Bandar Lampung menyatakan bahwa pembelajaran yang dilakukan saat ini belum efektif, karena pendidik masih dijadikan sebagai pusat informasi dalam pembelajaran. Hal ini terjadi karena kurangnya variasi bahan ajar yang sesuai dengan kebutuhan sehingga peserta didik sulit untuk memahami materi tanpa bantuan penuh dari pendidik. Maka dari itu, hal ini dapat memicu ketidakmandirian peserta didik dan juga memicu ketidakefektifan hasil dari pembelajaran matematika yang ada, sehingga belum memperoleh hasil yang memuaskan khususnya pada materi trigonometri pada kelas X. Khasan et al (2015), menyebutkan bahwa kemandirian sangat penting dalam membangun berpikir matematis. Kurangnya kemandirian, akan berdampak kepada hambatan pembelajaran matematis itu sendiri.

Adapun hasil angket analisis kebutuhan peserta didik yang disebutkan bahwa pada pengisian angket dilakukan sebanyak 60 peserta didik yang masing-masing 30 peserta didik dari SMAN 5 Bandar Lampung dan MAN 2 Bandar Lampung. Adapun skor yang diperoleh adalah $80 \%$ atau setara dengan 48 peserta didik menyatakan bahwa matematika merupakan mata pelajaran yang materi nya sulit untuk dimengerti, lalu 60\% atau setara dengan 36 peserta didik mengatakan bahwa bahan ajar yang selama ini digunakan belum menggunakan model pembelajaran.

Oleh karena itu, untuk membantu permasalahan tersebut dibutuhkan bahan ajar berupa modul yang dipadukan dengan model pembelajaran tertentu yang bertujuan agar selama proses pembelajaran peserta didik dapat belajar secara mandiri dengan menggunakan modul, peserta didik juga memiliki pengalaman langsung melalui kegiatan-kegiatan sesuai sintaks yang dimiliki model tersebut. Hartono dan Noto (2017) menyatakan bahwa modul pembelajaran yang selaras, akan membantu peserta didik mengalami.

Model yang dipilih dalam penelitian ini adalah model pembelajaran POE (Predict, Observe, Explain). Dalam kegiatan belajar dibutuhkan bahan ajar berupa modul yang dipadukan dengan model pembelajaran tertentu yang bertujuan agar selama proses pembelajaran peserta didik dapat belajar secara mandiri dengan menggunakan modul, peserta didik juga memiliki pengalaman langsung melalui kegiatan-kegiatan sesuai sintaks yang dimiliki model tersebut (Fannie dan Rohati, 2014; Farikha et al, 2015; Mutlu dan Şeşen, 2016).

Model POE adalah salah satu alternatif yang dapat digunakan oleh para pendidik untuk menciptakan suasana belajar yang menyenangkan dan berkualitas. Model POE dinyatakan sebagai pembelajaran yang efisien untuk memperoleh dan meningkatkan konsepsi sains peserta didik, serta menimbulkan ide atau gagasan peserta didik (Restami, et al, 2013). Prosedur POE adalah meliputi prediksi peserta didik dari hasil demonstrasi atau mengamati, mendiskusikan alasan dari prediksi 
yang mereka berikan dari hasil demonstrasi atau mengamati, dan terakhir menjelaskan hasil prediksi dari pengamatan mereka (Indriana et $a l, 2015)$. Berdasarkan penjabaran diatas, maka perlu adanya suatu pengembangan bahan ajar berupa modul matematika berbasis $\mathrm{POE}$, sehingga kesulitan yang menjadi kendala bagi peserta didik selama ini dapat di minimalisir.

\section{METODE}

Jenis penelitian yang dilakukan adalah penelitian pengembangan (Research and Development). Menurut Sugiyono (2015) metode penelitian merupakan cara ilmiah untuk mendapatkan data dengan tujuan dan kegunaan tertentu. Penelitian pengembangan ini dilaksanakan di SMAN 5 Bandar Lampung dan MAN 2 Bandar Lampung. Dalam hal ini penelitian ini menggunakan metode penelitian pengembangan perangkat $4 \mathrm{D}$ (four $D$ model). Model pengembangan ini dipilih karena merupakan model pengembangan yang disarankan dalam pengembangan perangkat pembelajaran (Trianto, 2014). Alur empat tahap utama model pengembangan $4 \mathrm{D}$ dapat dilihat pada Gambar 1.

Bagan diatas merupakan alur empat tahap utama pada model pengembangan 4D. secara konseptual, model pengembangan $4 \mathrm{D}$ mencakup empat tahapan sebagai berikut: (1) Pendefinisian (define) memiliki tujuan untuk melakukan analisis kebutuhan atau pengumpulan informasi-informasi yang berkaitan dengan produk yang akan dikembangkan. Tahapan dalam pendefinisan ini adalah analisis awal, analisis konsep, analisis tugas dan spesifikasi tujuan pembelajaran; (2) Perancangan (design) merupakan tahapan dengan tujuan untuk merancang produk dengan melakukan tahap kegiatan yaitu pemilihan media, pemilihan format dan melakukan rancangan awal; (3) Pengembangan (develop) merupakan tahap dengan tujuan untuk menghasilkan sebuah produk dengan melakukan uji kelayakan/ validasi produk yang dikembangkan kepada validator dengan dua validator ahli pada bidangnya masing-masing yaitu ahli materi dan ahli media, selain itu setelah mendapat validasi dari para ahli tahap selanjutnya yaitu melakukan revisi berdasarkan masukan dan saran para ahli lalu melakukan tahap uji coba; (4) Penyebaran (disseminate) merupakan tahap akhir yaitu melakukan penyebaran berupa produk yang dihasilkan yaitu modul matematika dengan menggunakan model pembelajaran POE pada materi trigonometri. Dalam penelitian ini dilakukan tiga analisis, yaitu analisis kelayakan bahan ajar, analisis kemenarikan bahan ajar dan keefektivan bahan ajar. Analisis kelayakan bahan ajar diperoleh dari validasi materi dan media, analisis kemenarikan diperoleh dari angket respon peserta didik dapat dilihat dari Tabel 1.

Tabel. 1 Kriteria Kelayakan dan Kemenarikan

\begin{tabular}{cc}
\hline Skor Kualitas & Kriteria Kelayakan \\
\hline $1<\bar{x} \leq 1,76$ & Tidak Layak \\
$1,76<\bar{x} \leq 2,51$ & Kurang Layak \\
$2,51<\bar{x} \leq 3,26$ & Layak \\
$3,26<\bar{x} \leq 4$ & Sangat Layak \\
\hline
\end{tabular}

Tingkat keefektifan modul diperoleh dari menghitung nilai n-gain dari hasil pre-test dan post-test pada hasil belajar peserta didik. Menghitung n-gain menggunakan rumus Hake R.R sebagai berikut: $N$-gain $=\frac{S_{\text {post }-S_{\text {pre }}}}{S_{\text {maks }}-S_{\text {pre }}}$ dengan $S_{\text {post }}$ adalah Skor posttest; $S_{\text {pre }}$ adalah Skor pretest, dan $s_{\text {maks }}$ adalah Skor maksimum ideal. Kriteria tingkat keefektifan produk yang dibuat disajikan dalam Tabel 2.

Tabel. 2 Skor Penilaian Uji Coba

\begin{tabular}{cc}
\hline Kriteria pencapaian nilai & Tingkat Efektivitas \\
\hline $\mathrm{n}$-gain & Efektivitas rendah \\
0,3 n-gain & Efektivitas sedang \\
$\mathrm{n}$-gain & Efektivitas tinggi \\
\hline
\end{tabular}

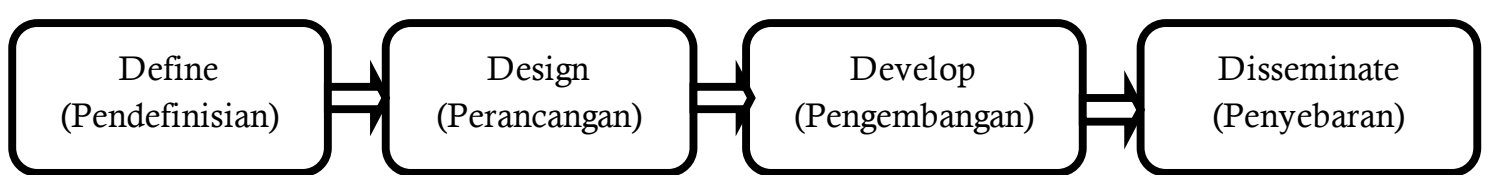

Gambar 1. Alur Tahap utama model pengembangan $4 D$ 


\section{HASIL DAN PEMBAHASAN Hasil Penelitian Tahap Define}

Analisis Awal. Analisis awal merupakan analisis dengan acuan terhadap keadaan lapangan yang memiliki tujuan untuk mengetahui kebutuhan produk yang akan dikembangkan. Data dari analisis awal ini diperoleh dari hasil wawancara dengan seorang guru matematika dan diperoleh dari hasil penyebaran angket kepada siswa. Wawancara yang dilakukan pada tahap analisis awal ini menyatakan bahwa peserta didik memiliki kesulitan untuk memahami konsep ataupun mengoperasikan perhitungan matematika dan juga rendahnya kemandirian peserta didikpada saat kegiatan belajar berlangsung. Dengan demikian, modul yang dikembangkan ini diharapkan menjadi bahan ajar yang sistematis untuk dijadikan sebagai bahan ajar tambahan pada kegiatan pembelajaran. Salah satu karakteristik modul itu adalah sangat bersahabat dengan pembacanya, maka modul ini diharapkan akan mempermudah peserta didik dalam belajar.

Pengembangan modul ini dibuat dengan bantuan model pembelajaran POE yang dikemas secara terstruktur dan sistematis. Materi yang disajikan dalam modul dibuat semenarik mungkin agar mudah dipahami peserta didik dengan mandiri. Adapun pada analisis awal juga dilakukan penyebaran angket kepada peserta didikkelas X SMAN 5 Bandar Lampung dan MAN 2 Bandar Lampung. Penyebaran angket ditujukan kepada 60 peserta didik dimana 30 peserta didik merupakan siswa SMAN 5 Bandar Lampung dan 30 peserta didik lainnya adalah siswa MAN 2 Bandar Lampung. Berdasarkan dari penyebaran angket tersebut diperoleh hasil yang menyatakan bahwa terdapat $80 \%$ dari 60 peserta didik merasa mengalami kesulitan untuk memahami mata pelajaran matematika dan $60 \%$ dari 60 peserta didik ingin mencoba belajar matematika dengan bantuan modul yang dipadukan dengan model pembelajaran khusus untuk memudahkan peserta didik dalam memahami materi pelajaran.

Analisis Konsep. Disesuaikan dengan penelitian yang dilakukan didua sekolah berbeda Bandar Lampung yakni SMAN 5 Bandar Lam- pung dan MAN 2 Bandar Lampung. Peneliti menyusun materi menjadi tiga bab diantaranya bab trigonometri, bab aturan sinus dan cosinus serta bab fungsi trigonometri.

AnalisisTugas. Tahap berikutnya yaitu melakukan analisis tugas. Kegiatan yang dilakukan adalah menganalisa tugas pokok yang perlu dikuasai oleh peserta didik agar mampu mencapai kompetensi minimal yang ada. Setelahmelakukan analisa tersebut selanjutnya akan diperoleh gambaran contoh soal serta latihan soal per bab untuktrigonometri dengan menggunakan model pembelajaran POE.

Spesifikasi Tujuan Pembelajaran. Kegiatan yangdilakukan adalah merangkum hasil dari analisis awal hingga analisis tugas kemudian dirumuskan tujuannya untuk menentukan perilaku objek penelitian.Merancang dan menyusun produk yang akan dikembangkan merupakan keseluruhan objek dari hasil ketiga analisis tersebut. Kemudian dari hasil analisis tersebut diperoleh tujuan pembelajaran yang harus dicapaipeserta didik dari produk yang dikembangkan berupa bahan ajar modul berbasis POE pada materi trigonometri tersebut

\section{Tahap Desain}

Pada tahap perancangan atau designterdapat beberapa tahapan, diantaranya: Pemilihan Media. Media yang dipilih adalah modul matematika dengan menggunakan model pembelajaran POE pada materi trigonometri. Pemilihan Format. Dalam pembuatan modul ini bagian isi diketik menggunakan Microsoft wrord 2010 dan ukuran kertas B5 dengan spasiyang digunakan1,5; adapun digunakannya dua jenis huruf yakni jenis huruf untuk judul bab adalah Bodoni MT Blackdan Comic Sans MS untuk judul sub bab bagian isi. Sedangkan pada cover bagian depan dan bagian belakang menggunakan Corel draw $X_{4}$ serta Geogebra untuk digunakan dalam pembuatan fungsi grafik trigonometri.

Rancangan Awal. Rancangan awal mengenai produk yang akan dibuat yaitu modul diantaranya terdiri dari bagian awal, bagian isi dan bagian penutup. Pada bagian awal terdapat dua cover yakni bagian depan dan juga bagian cover dalam yang mencakup nama penulis, nama pendesain dan nama pembimbing pada penelitian ini. Selain itu pada bagian 
Adapun Perbandingan hasil validasi ahli materi pada tahap 1 dan 2 dapat dilihat pada Gambar 2.

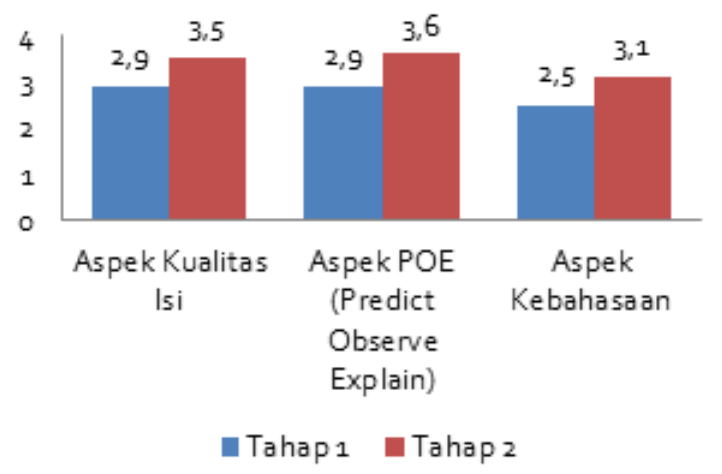

Gambar. 2 Perbandingan Hasil Validasi Ahli Materi Tahap 1 dan 2

Berdasarkan gambar 2 tersebut grafik perbandingan hasil validasi ahli materi tahap 1 dan tahap 2 terlihat bahwa adanya peningkatan dari ketiga aspek yang ada. Hasil validasi ahli materi tahap 1 mengalami peningkatan pada tahap ke 2. Nilai pada aspek isi pada tahap 1 diperoleh rata-rata 2,9 dengan kriteria "layak" dan pada tahap ke 2 diperoleh ratarata skor sebesar 3,5 dengan kriteria " sangat layak". Pada aspek POE (Predict Observe Expalin) pada tahap 1 diperoleh nilai rata-rata sebesar 2,6 dengan kriteria "layak" dan pada tahap 2 diperoleh skor rata-rata sebesar 3,6 dengan kriteria " sangat layak". Sedangkan pada aspek kebahasaan pada tahap 1 diperoleh nilai rata-rata sebesar 2,5 dengan kriteria "kurang layak" dan pada tahap 2 diperoleh skor ratarata sebesar 3,1 dengan kriteria "layak". Maka dari itu, dari ketiga aspek tersebut dinyatakan valid dan modul trigonometri dengan model pembelajaran POE (Predict Observe Explain) sudah layak untuk digunakan. Hasil validasi ahli media tahap 1 dapat dilihat pada Tabel 5.

Hasil penilaian oleh validator ahli media secara keseluruhan memiliki nilai rata-rata sebesar 2,5 dengan kriteria "kurang layak". Sehingga dapat disimpulkan bahwa modul perlu dilakukan perbaikan sehingga dapat dikatakan layak untuk digunakan. Setelah dilakukan validasi tahap 1 dan modul yang dibuat telah direvisi,maka selanjutnya akan dilakukan validasi ahli media tahap 2. Validasi ahli media tahap 2 mempunyai tujuan untuk melihat kri- teria hasil modul yang direvisi atau diperbaiki oleh peneliti. Hasil ahli media tahap 2 dapat dilihat pada Tabel 6.

Tabel. 5 Hasil Validasi Ahli Media tahap 1

\begin{tabular}{|c|c|c|c|c|}
\hline \multirow{2}{*}{ Aspek } & \multirow{2}{*}{ Analisis } & \multicolumn{3}{|c|}{ Validator } \\
\hline & & 1 & 2 & 3 \\
\hline \multirow{3}{*}{$\begin{array}{l}\text { Ukuran } \\
\text { Modul }\end{array}$} & Jumlah Skor & 6 & 6 & 5 \\
\hline & & \multicolumn{3}{|c|}{2,8} \\
\hline & Kriteria & \multicolumn{3}{|c|}{ Layak } \\
\hline \multirow{4}{*}{$\begin{array}{l}\text { Desain Kulit } \\
\text { Modul (Cover) }\end{array}$} & Jumlah Skor & 10 & 9 & 11 \\
\hline & & 2,5 & 2,2 & 2,7 \\
\hline & & \multicolumn{3}{|c|}{2,4} \\
\hline & Kriteria & \multicolumn{3}{|c|}{ Kurang layak } \\
\hline \multirow{4}{*}{$\begin{array}{l}\text { Desain Isi } \\
\text { Modul }\end{array}$} & Jumlah Skor & 24 & 26 & 24 \\
\hline & & 2,4 & 2,6 & 2,4 \\
\hline & & \multicolumn{3}{|c|}{2,4} \\
\hline & Kriteria & \multicolumn{3}{|c|}{ Kurang layak } \\
\hline \multicolumn{2}{|l|}{ Rata-rata Total } & \multicolumn{3}{|c|}{2,5} \\
\hline \multicolumn{2}{|l|}{ Kriteria } & \multicolumn{3}{|c|}{ Kurang layak } \\
\hline
\end{tabular}

Tabel. 6 Hasil Validasi Ahli Media tahap 2

\begin{tabular}{|c|c|c|c|c|}
\hline \multirow{2}{*}{ Aspek } & \multirow{2}{*}{ Analisis } & \multicolumn{3}{|c|}{ Validator } \\
\hline & & 1 & 2 & 3 \\
\hline \multirow{3}{*}{$\begin{array}{l}\text { Ukuran } \\
\text { Modul }\end{array}$} & Jumlah Skor & 7 & 7 & 6 \\
\hline & & 3,5 & $\begin{array}{c}3,5 \\
2,8\end{array}$ & 3 \\
\hline & Kriteria & & Layak & \\
\hline \multirow{3}{*}{$\begin{array}{l}\text { Desain } \\
\text { Kulit Modul } \\
\text { (Cover) }\end{array}$} & Jumlah Skor & 15 & 13 & 12 \\
\hline & & 3,7 & 3,2 & 3 \\
\hline & Kriteria & S & $\begin{array}{c}3,3 \\
\text { ngat la }\end{array}$ & \\
\hline \multirow{4}{*}{$\begin{array}{l}\text { Desain Isi } \\
\text { Modul }\end{array}$} & Jumlah Skor & 28 & 34 & 26 \\
\hline & & 2,8 & 3,4 & 2,6 \\
\hline & & & 2,9 & \\
\hline & Kriteria & & Layak & \\
\hline \multicolumn{2}{|c|}{ Rata-rata Total } & \multicolumn{3}{|c|}{3,1} \\
\hline \multicolumn{2}{|l|}{ Kriteria } & \multicolumn{3}{|c|}{ Layak } \\
\hline
\end{tabular}

Perbandingan hasil validasi ahli media pada tahap 1 dan tahap 2 dapat dilihat pada Gambar 3.

Berdasarkan Gambar 3 grafik perbandingan hasil validasi tahap 1 dan tahap 2 terlihat bahwa terdapat peningkatan dari ketiga aspek yang ada. Hasil validasi ahli media mengalami peningkatan pada tahap ke 2 . Nilai pada aspek ukuran modul pada tahap 1 diperoleh nilai rata-rata 2,8 dengan kriteria " 
layak" dan pada tahap 2 rata-rata skor sebesar 3,3 dengan kriteria "sangat layak". Pada aspek desain kulit modul pada tahap 1 diperoleh nilai skor sebesar 2,4 dengan kriteria "kurang layak" dan pada tahap 2 diperoleh skor sebesar 3,3 dengan kriteria "sangat layak". Pada aspek desain isi modul diperoleh nilai rata-rata sebesar 2,4 dengan kriteria "kurang layak" dan pada tahap ke 2 diperoleh skor sebesar 2,9 dengan kriteria "layak". Maka dari itu, dari ketiga aspek tersebut dinyatakan valid dan modul trigonometri dengan model pembelajaran POE (Predict Observe Explain) layak untuk digunakan.

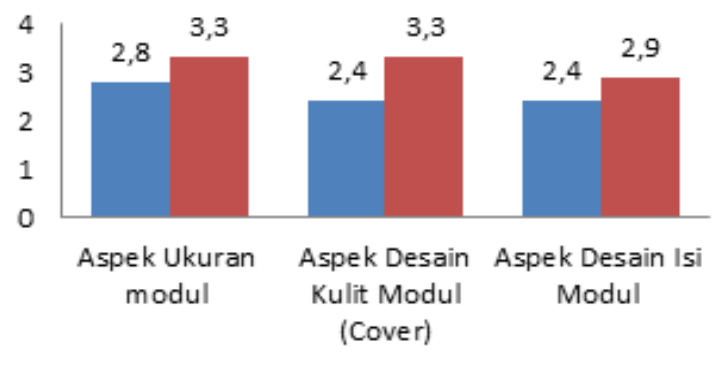

- Tahap 1 Tahap 2

Gambar. 3 Perbandingan Hasil Validasi Ahli Media Tahap 1 dan 2

Setelah produk selesai divalidasi dan dinyatakan layak oleh ahli materi dan ahli media. Maka modul trigonometri dengan menggunakan model pembelajaran POE (Predict Observe Explain) siap untuk diuji cobakan kepada peserta didik. Uji coba dilakukan dengan dua kelompok yaitu uji coba kelompok kecil terdiri dari 10 peserta didik dan uji coba kelompok besar terdiri dari 30 peserta didik.

Berdasarkan Tabel 9 hasil uji efektivitas yang diperoleh dari masing-masing 30 peserta didik dari SMAN 5 Banar Lampung dan MAN 2 Bandar Lampung diperoleh nilai N-Gain masing-masing adalah 0,72 dan 0,70 yang keduanya memiliki kriteria "Tinggi", adapun nilai rata-rata N-Gain secara keseluruhan adalah 0,71 dengan kriteria "Tinggi".

\section{Tahap Disseminate}

Penyebaran yang dilakukandalam penelitian pengembangan iniadalah dengan memberikan modul dalam bentuk hardcopy kepada peserta didik secara perwakilan dari masing-masing sekolah SMAN 5 Bandar Lampung dan MAN 2 Bandar Lampung.

\section{Pembahasan}

Penelitian dan pengembangan ini memiliki tujuan untuk mengetahui bagaimana cara mengembangkan produk berupa modul dengan bantuan model pembelajaran POE pada materi trigonometri, selain itupun penelitian ini bertujuanmengetahui bagaimana respon peserta didik, seberapa layak modul yang dikembangkan dan seberapa efektif modul yang dikembangkan. Modul yang dikembangkan berbasis model pembelajaran POE yang didalamnya terdapat penjelasan materi, contoh soal, latihan soal serta evaluasi juga motivasi untuk membangkitkan semangat pe-

Tabel. 7 Hasil Uji Coba Kelompok Kecil

\begin{tabular}{|c|c|c|c|c|c|c|}
\hline \multicolumn{2}{|c|}{ Nama Sekolah } & Nilai & Kategori & ata-rata & \multicolumn{2}{|c|}{ Kategori } \\
\hline \multirow{2}{*}{\multicolumn{2}{|c|}{$\begin{array}{l}\text { SMAN }_{5} \\
\text { MAN } 2\end{array}$}} & 3,4 & Sangat menarik & \multirow[b]{2}{*}{3,3} & \multirow{2}{*}{\multicolumn{2}{|c|}{ Sangat menarik }} \\
\hline & & 3,3 & Menarik & & & \\
\hline \multicolumn{7}{|c|}{ Tabel. 8 Hasil Uji Coba Kelompok Besar } \\
\hline \multicolumn{2}{|c|}{ Nama Sekolah } & Nilai & Kategori & Rata-rata & \multicolumn{2}{|c|}{ Kategori } \\
\hline \multirow{2}{*}{\multicolumn{2}{|c|}{$\begin{array}{l}\text { SMAN } 5 \\
\text { MAN } 2\end{array}$}} & 3,4 & Sangat menarik & \multirow{2}{*}{3,3} & \multirow{2}{*}{\multicolumn{2}{|c|}{ Sangat menarik }} \\
\hline & & 3,3 & Sangat menarik & & & \\
\hline \multicolumn{7}{|c|}{ Tabel. 9 Hasil Uji Coba Efektivitas } \\
\hline Sekolah & Pre-test & Post-test & Jumlah Peserta Didik & Gain & N-Gain & Kriteria \\
\hline SMAN $_{5}$ & 69,50 & 91,17 & 30 & 21,67 & 0,72 & Tinggi \\
\hline MAN 2 & 60,83 & 87,83 & 30 & 27 & 0,70 & Tinggi \\
\hline Rata-rata & J-Gain & & & 0,71 & & \\
\hline Kriteria & & & & Tinggi & & \\
\hline
\end{tabular}


serta didik dalam belajar. Hasil temuan dalam penelitian tersebut selaras dengan penelitian Lasmiyati dan Harta (2014), yang menyatakan bahwa belajar menggunakan modul akan dapat meningkatkan pemahaman konsep peserta didik. Selain itu minat belajar peserta didik juga akan ikut meningkat. Dengan kombinasi belajar denga modul dan pembelajaran $\mathrm{POE}$, diyakini bahwa kemampuan berpikir kreatif dan prestasi peserta didik akan meningkat. Hasil penelitian Anggoro (2015) dan Anisa et al (2013) dikuatkan dengan hasil penelitian ini.

Penelitian ini menggunakan metode Research and Development (R\&D) dan menggunakan prosedur pengembangan 4-D (Define, Design, Develop, Dessiminate). Modul yang dikembangkan di validasi oleh ahli materi dan ahli media yang masing-masing adalah tiga validator ahli, dari setiap hasil validasi tahap 1 dan tahap 2 selalu mengalami peningkatan. Adapun setelah dilakukannya validasi maka dilakukan kegiatan uji coba produk yang mana kegiatan ini bertujuan untuk mengetahui respon peserta didik terhadap tingkat kemenarikan modul yang dikembangkan.

Uji coba tersebut dilakukan secara tiga tahap yaitu uji coba kelompok kecil yang masing-masing terdiri dari 10 peserta didik dari SMAN 5 Bandar Lampung dan MAN 2 Bandar Lampung. Selanjutnya uji coba kelompok besar terdiri dari masing-masing 30 peserta didik dari SMAN 5 Bandar Lampung dan MAN 2 Bandar Lampung yang diperoleh hasil secara keseluruhan adalah sangat menarik. Hasil uji coba kelompok kecil dapat dilihat pada Tabel 7 dan hasil uji coba kelompok besar dapat dilihat pada Tabel 8 . Sehingga modul layak dan menarik untuk dilakukan uji efektifitas.

Uji efektifitas dilakukan pada kelas yang sama dengan uji kelompok besar yang terdiri dari masing-masing 30 peserta didik dari SMAN 5 Bandar Lampung dan MAN 2 Bandar Lampung. Kegiatan yang dilakukan pada uji efektifitas ini adalah dengan melakukan pretestsebelum memulai kegiatan pembelajaran setelah itu menyampaikan materi menggunakan modul yang dikembangkan dengan menggunakan model pembelajaran POE dan diakhiri dengan melakukan posttest kepada peserta didik.

Hasil yang diperoleh dari hasil uji efek- tifitas ini adalah nilai rata-rata $\mathrm{N}$-gain yaitu 0,71 dengan kriteria Tinggi dengan masingmasing perolehan $\mathrm{N}$-gain nya adalah 0,72 untuk SMAN 5 Bandar Lampung dan 0,70 untuk MAN 2 Bandar Lampung dengan kriteria tinggi. Adapun nilai $\mathrm{N}$-gain yang diperoleh MAN 2 Bandar Lampung 0,70 pada kelas X IPA 1 tidak lebih besar dari perolehan hasil nilai $\mathrm{N}$ gain SMAN 5 Bandar Lampung di kelas X IPS 2 hal ini dikarenakan selisih nilai pretest terhadap posttest di MAN 2 Bandar Lampung tidak mengalami peningkatan yang signifikan sedangkan di SMAN 5 Bandar Lampung perolehan hasil nilai pretestdan posttest mengalami peningkatan yang sangat signifikan sehingga perolehan $\mathrm{N}$-gain nya pun sangat tinggi dan baik. Rosyida dan Jailani (2014) melakukan kegiatan yang hamper serupa. MOdul matematika yang dikembangkan memang berbeda dengan modul dalam penelitian ini. Namun, hasil penelitian ini menguatkan penelitian sebelumnya yang menampakkan fakta bahwa peningkatan prestasi peserta didik terjadi, saat mereka belajar dengan modul yang dihasilkan.

\section{PENUTUP}

\section{Simpulan}

Berdasarkan hasil penelitian dan pembahasan di atas, simpulan yang diperoleh adalah produk berupa bahan ajar modul trigonometri dengan menggunakan model pembelajaran POE efektif digunakan dalam pembelajaran untuk jenjang SMA/MA. Efektif dimaknai dengan modul tersebut sangat layak digunakan, sangat menarik, dan menghasilkan prestasi belajar peserta didik yang tinggi.

\section{DAFTAR PUSTAKA}

Anggoro, B. S. (2015). Pengembangan Modul Matematika Dengan Strategi Problem Solving untuk Mengukur Tingkat Kemampuan Berpikir Kreatif Matematis Siswa. Al-Jabar: Jurnal Pendidikan Matematika, 6(2), 121-130.

Anisa, D. N., Masykuri, M., \&Yamtinah, S. (2013). Pengaruh Model Pembelajaran POE (Predict, Observe, And Explanation) dan Sikap IImiah terhadap Prestasi Belajar Siswa pada Materi Asam, Basa dan Garam Kelas VII semester 1 SMP N 1 Jaten tahun pelajaran 2012/2013. Jurnal Pendidikan Kimia, 2(2), 16-23.

Fannie, R. D., \& Rohati, R. (2014). Pengembangan Lem- 
bar Kerja Siswa (LKS) Berbasis POE (Predict, Observe, Explain) pada Materi Program Linear Kelas XII SMA. Sainmatika: Jurnal Sains dan Matematika Universitas Jambi, 8(1).

Farikha, L. I., Redjeki, T., \& Utomo, S. B. (2015). Penerapan Model Pembelajaran Predict Observe Explain (POE) Disertai Eksperimen pada Materi Pokok Hidrolisis Garam untuk Meningkatkan Aktivitas dan Prestasi Belajar Siswa Kelas XI MIA 3 SMA Negeri 4 Surakarta Tahun Pelajaran 2014/2015. Jurnal Pendidikan Kimia, 4(4), 95-102.

Hartono, W., \& Noto, M. S. (2017). Pengembangan mod$\mathrm{ul}$ berbasis penemuan terbimbing untuk meningkatkan kemampuan matematis pada perkuliahan kalkulus integral. JNPM (Jurnal Nasional Pendidikan Matematika), 1(2), 320-333.

Indriana, V., Arsyad, N., \& Mulbar, U. (2015). Penerapan pendekatan pembelajaran POE (PredictObserve-Explain) untuk Meningkatkan Kemampuan Berpikir Kreatif Siswa Kelas XI IPA-1 SMAN 22 Makassar. Daya Matematis: Jurnal Inovasi Pendidikan Matematika, 3(1), 51-62.

Khasan, K., Dafik, D., \& Hobri, H. (2015). Pengembangan Perangkat Pembelajaran Matematika Berbasis Whole Brain Teaching Dengan Pendekatan Quantum Learning Pada Sub Pokok Bahasan Segitiga untuk SMP Kelas VII. Pancaran Pendidikan, 4(2), 143-152.

Lasmiyati, L., \& Harta, I. (2014). Pengembangan Modul Pembelajaran untuk Meningkatkan Pemahaman Konsep dan Minat SMP. Pythagoras: Jurnal Pendidikan Matematika, 9(2), 161-174.

Maskur, R., Nofrizal, N., \& Syazali, M. (2017). Pengembangan Media Pembelajaran Matematika dengan Macromedia Flash. Al-Jabar: Jurnal Pendidikan Matematika, 8(2), 177-186.
Mutlu, A., \& Şeşen, B.A. (2016). Predict-Observe-Explain Tasks in Chemistry Laboratory: Pre-service Elementary Teachers' Understanding and Attitudes. Sakarya University Journal of Education, 6(2), 184-208.

Netriwati, N. (2016). Analisis Kemampuan Mahasiswa dalam Pemecahkan Masalah Matematis menurut Teori Polya. Al-Jabar: Jurnal Pendidikan Matematika, 7(2), 181-19o.

Putra, R. W. Y., \& Anggraini, R. (2016). Pengembangan Bahan Ajar Materi Trigonometri Berbantuan Software iMindMap pada Siswa SMA. Al-Jabar: Jurnal Pendidikan Matematika, 7(1), 39-47.

Restami, M.P., Suma, K., \& Pujani, M. (2013). Pengaruh Model Pembelajaran POE (Predict-Observe-Explaint) Terhadap Pemahaman Konsep Fisika dan Sikap Ilmiah Ditinjau Dari Gaya Belajar Siswa. Jurnal Pendidikan dan Pembelajaran IPA Indonesia, 3(1).

Rhosyida, N., \& Jailani, J. (2014). Pengembangan Modul Matematika SMK Bidang Seni, Kerajinan, dan Pariwisata Berbasis Open-Ended Problem sebagai Implementasi KTSP. Jurnal Riset Pendidikan Matematika, 1(1), 35-47.

Sugiyono. (2015). Metode Penelitian Pendidikan (Research and Development). Bandung: Alfabeta.

Trianto. (2014). Model Pembelajaran Terpadu Konsep, Strategi dan Implementasinya Dalam Kurikulum Tingkat Satuan Pendidikan. Jakarta: Bumi Aksara.

Yusnita, I., Maskur, R., \& Suherman, S. (2016). Modifikasi model pembelajaran Gerlach dan Ely melalui integrasi nilai-nilai keislaman sebagai upaya meningkatkan kemampuan representasi matematis. Al-Jabar: Jurnal Pendidikan Matematika, 7(1), 29-38. 